\title{
Characterization and evaluation of cholinesterase activity in the cockle Cerastoderma glaucum
}

\author{
Jamel Jebali*, Sana Ben-Khedher, Nawel Kamel, Jihene Ghedira, Zied Bouraoui, \\ Hamadi Boussetta
}

Laboratory of Biochemical and Environmental Toxicology, Higher Institute of Agriculture, Chott-Mariem, 4042-Sousse, Tunisia

\begin{abstract}
The aim of the present study was to partially characterize the biochemical properties of cholinesterase (ChE) activity in the tissues of the cockle Cerastoderma glaucum, using different substrates and sample volumes, and to evaluate ChE response following caging exposure in a fishing harbour. Comparative analysis of the Michaelis-Menten kinetics in the studied tissues of C. glaucum indicated that ChE activity, using acetylthiocholine as substrate, displayed a tissuedependent response, with activity levels in the following order of magnitude: whole animal $>$ rest of animal (adductor and retractor muscles, mantle and foot) $>$ visceral mass $>$ gills. The transfer of C. glaucum to the Téboulba fishing harbour caused a time-dependent reduction in acetylcholinesterase activity.
\end{abstract}

KEY WORDS: Biomarker · Cockle · Cerastoderma glaucum • Cholinesterase · ChE · Caging • Fishing harbour

Resale or republication not permitted without written consent of the publisher

\section{INTRODUCTION}

The marine ecosystem is continuously being affected by various types of chemical pollutants. The development of sensitive ecotoxicological tools for impact assessment is therefore a priority task. Stress indices, or biomarkers, have been employed in ecotoxicological studies to assess the negative effects of contaminants in aquatic organisms, bivalves in particular, and to define environmental quality (LópezBarea 1995). Among the biomarkers evaluated to date, there is a lot of interest in cholinesterase (ChE) activity as an indicator of the biological effects of exposure to neurotoxic compounds in aquatic organisms (Bocquené \& Galgani 1991).

ChEs are a family of enzymes that includes acetylcholinesterase (AChE) or true cholinesterase and pseudocholinesterases (PsChE). AChE plays an important role in neurotransmission in both vertebrates and invertebrates, being responsible for the hydrolysis of acetylcholine into choline and acetic acid at the cholinergic synapses and neuromuscular junctions. PsChE seems to have no specific natural substrates and has been proposed as a scavenging enzyme for certain classes of toxic compound (Massoulié et al. 2008). In vertebrates, ChEs may be distinguished by their functional characteristics of substrate specificity and their susceptibility to diagnostic inhibitors (Sturm et al. 1999, Massoulié et al. 1993, 2008). Among selective inhibitors currently used to classify vertebrate ChEs, phenylmethylsulphonyl fluoride (PMSF) is a general inhibitor of enzymes having Ser residues in their active site, such as ChEs (Galloway et al. 2002), whereas tetra (monoisopropyl) pyrophosphor-tetramide (Iso-OMPA) and 1,5-bis (4-allyldimethylammoniumphenyl) pentan-3-one dibromide (BW284c51) are considered selective for butyrylthiocholine (BChE) and $\mathrm{AChE}$, respectively, in vertebrates (Sturm et al. 1999). However, the classification used for vertebrates may be inappropriate for invertebrates such as bivalves (Bocquené et al. 1997). In aquatic invertebrates, classification of ChE isoforms 
has been less studied than in vertebrates. Moreover, most studies have been mainly focused on marine and freshwater species, such as molluscs (Mora et al. 1999, Corsi et al. 2007), different orders of Crustacea (Xuereb et al. 2007, Vioque-Fernández et al. 2007) and Copepoda (Monserrat \& Bianchini 1998). Therefore, the use of ChE activity as an environmental biomarker requires a careful characterization of the enzymes present in a given species and tissue to minimize possible erroneous interpretation of the results (Vioque-Fernández et al. 2009a,b). To the best of our knowledge, ChE activity in tissues of the cockle Cerastoderma glaucum has not been characterized to date.

Bivalve organisms such as clams have been widely used as sentinel organisms in previous field studies because of their wide geographical distribution and ability to accumulate contaminants (Banni et al. 2005, Jebali et al. 2007). In addition to their higher capacity to accumulate contaminants, bivalves can be easily caged at field sites. Using caged bivalves from a single population avoids bias related to age and reproductive status of the organisms that influence contaminant bioaccumulation and biomarker responses and allows a more accurate assessment of the real biological effects of contaminants over a predetermined exposure period (Oikari 2006). In the present study, wild Cerastoderma glaucum were transplanted into a fishing harbour to illustrate the kinetic responses of ChE activity using acetylthiocholine as substrate under natural conditions. The aims of the present study were to: (1) partially characterize the biochemical properties of ChE activity in the main tissues of C. glaucum, using different substrates and sample volumes, and (2) evaluate its response following the caging exposure in a fishing harbour.

\section{MATERIALS AND METHODS}

\section{Chemicals}

Acetyl- (ASCh), propionyl- (PSCh) and butyrylthiocholine (BSCh), all in their iodide forms, and dithiobisnitrobenzoate (DTNB) as well as all other reagents were purchased from Sigma-Aldrich.

\section{Cockle sampling and experimental caging technique}

Wild Cerastoderma glaucum were manually collected at Kuriat Island (Tunisia), an uncontaminated area, in September 2008. After collection, bivalves were transported in a cold container by boat to Téboulba fishing harbour $\left(35^{\circ} 39^{\prime} \mathrm{N}, 10^{\circ} 57^{\prime} \mathrm{E}\right)$, where they were exposed to ambient conditions for 1 mo. Twenty specimens of $\sim 25 \mathrm{~mm}$ shell length were placed in a rectangular cage made of polyethylene netting $(20 \times 20 \times 50 \mathrm{~cm})$ and maintained at $2 \mathrm{~m}$ depth. After 0, 15 and 30 d, 10 bivalves were collected and immediately dissected. The tissues, i.e. gills, visceral mass and the rest of the animal (adductor and retractor muscles, mantle and foot), were carefully removed, placed in Eppendorf tubes and transported in a portable refrigerator to the laboratory. Samples were stored at $-40^{\circ} \mathrm{C}$ until analysis. For the C. glaucum-specific biochemical characterization of AChE, 40 animals from the same Kuriat Island population were transported in a portable refrigerator to the laboratory. Either the whole animal, its main organs (gills and visceral mass were dissected out) or the rest of the animal were placed individually in Eppendorf tubes and frozen at $-40^{\circ} \mathrm{C}$ until analysis.

\section{Sample preparation}

Tissues (whole animal, rest of animal, visceral mass and gills) were dissected and homogenized in icecold $100 \mathrm{mM}$ phosphate buffer, pH 7.4 (1/4 w/v) with an Ultra-Turrax T25 at $24000 \mathrm{rpm}$ for $30 \mathrm{~s}$. The homogenate was centrifuged at $9000 \times g$ at $4^{\circ} \mathrm{C}$ for $30 \mathrm{~min}$, and the supernatant was stored at $-40^{\circ} \mathrm{C}$ until biochemical assays were performed. Protein concentration was estimated according to Bradford (1976) using bovine serum albumin as standard.

\section{ChE activity}

ChE activity was measured using the method of Ellman et al. (1961). For an assay, $40 \mu \mathrm{l}$ of homogenate extract of each tissue group (gills, visceral mass, rest of animal and whole animal) was incubated at $25^{\circ} \mathrm{C}$ in a final volume of $1.2 \mathrm{ml}$ containing $100 \mathrm{mM}$ phosphate buffer (pH 7.5) and $50 \mu \mathrm{l}$ of $8 \mathrm{mM}$ DTNB. Measurement of enzyme activity was initiated by the addition of $75 \mu \mathrm{l}$ of freshly prepared $\mathrm{ASCh}, \mathrm{PSCh}$ or BSCh iodide solution in distilled water at $3 \mathrm{mM}$ final concentration. Absorption of the 2nitro-5-thiobenzoate anion, formed by the reaction, was then recorded at $412 \mathrm{~nm}$ every $60 \mathrm{~s}$ for $10 \mathrm{~min}$. A blank without substrate was used to evaluate the reaction of thiols with DTNB, and another without sample was used to estimate the rate of spontaneous substrate hydrolysis. 
ASCh was chosen as the routine substrate, as it is most commonly used for measuring ChE activity in invertebrate extracts and is considered the most specific for AChE (EC.3.1.1.7; Massoulié et al. 1993). For the determination of the kinetic constants of AChe activity, assays with ASCh concentrations ranging from 0.04 to $10 \mathrm{mM}$ were investigated in each of the tissue groups of Cerastoderma glaucum. The effect of sample volume (1 to $40 \mu \mathrm{l})$ was investigated to optimize the AChE assay conditions in C. glaucum.

\section{Statistical analysis}

Statistical analyses were performed using SPSS software. Significant differences between means were determined using one-way ANOVA followed by Duncan's test. Significant correlations between caging time and AChe responses were examined using Pearson correlation analysis.

In order to calculate the kinetic parameters of $\mathrm{AChE}$, such as the Michaelis-Menten constant $\left(K_{\mathrm{m}}\right)$, the maximum substrate hydrolysis velocity, and the catalytic efficiency $\left(v_{\max } / K_{\mathrm{m}}\right)$, we used GraphPad Prism v. 4 for Windows (GraphPad Software).

\section{RESULTS}

\section{Substrate affinity of ChE in tissue groups}

Preliminary screening to determine ChE substrate affinities in extracts of whole animal, rest of animal, visceral mass and gills was carried out at $3 \mathrm{mM}$ fixed concentration. As shown in Fig. 1, for each tissue group, there were significant differences in ChE activity among the 3 substrates. In whole animals, the highest ChE activity was obtained with ASCh. In the other 3 tissue groups, ChE activity was highest using PSCh, representing 46, 55 and $49 \%$ of the total ChE activity in the rest of animal, visceral mass and gills, respectively.

\section{Characterization of $\mathrm{AChE}$ activity versus ASCh}

\section{Effects of substrate concentration}

The effects of substrate concentrations ranging from 0.04 to $10 \mathrm{mM}$ on $\mathrm{AChE}$ activity versus $\mathrm{ASCh}$ were assayed in whole animal, rest of animal, visceral mass and gill extracts of Cerastoderma glaucum (Fig. 2). In all tissue groups, AChE activity

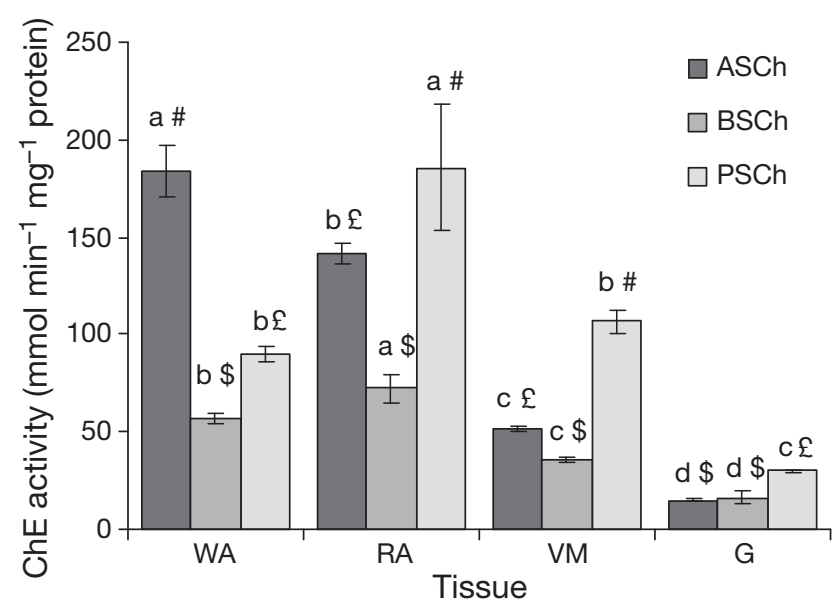

Fig. 1. Substrate specificity of cholinesterase (ChE) activity in the tissues of Cerastoderma glaucum. Data are means \pm SD of 4 determinations. Different lowercase letters indicate a significant difference between tissues. Significant differences between ChE activity in the same tissue are shown with different symbols. Substrates used were acetyl- (ASCh), butyryl- (BSCh) and propionylthiocholine (PSCh) iodide. WA: whole animal; RA: rest of animal (adductor and retractor mucsles, mantle and foot); VM: visceral mass; G: gills

depended on substrate concentrations. A slight decrease in activity was observed at high ASCh concentrations in whole animal, rest of animal and visceral mass. A maximum AChE activity of approx. $185,152,57$ and $20 \mathrm{nmol} \mathrm{min}{ }^{-1} \mathrm{mg}^{-1}$ protein were measured in the whole animal, rest of animal, visceral mass and gill, respectively, using $3 \mathrm{mM}$ ASCh at $\mathrm{pH}$ 7.5. This concentration was used for subsequent analysis (data not shown) as it was not rate limiting over the $10 \mathrm{~min}$ time period chosen.

The Michaelis-Menten kinetic parameters $\left(K_{\mathrm{m}}\right.$ $v_{\max }$ and $\left.v_{\max } / K_{\mathrm{m}}\right)$ are reported in Table 1 . The $K_{\mathrm{m}}$ value was higher in gills than in the other tissue groups; this low affinity was in agreement with the low $v_{\max } / K_{\mathrm{m}}$ value. AChE had a higher affinity towards ASCh as a substrate in the whole animal; this higher affinity was in agreement with the higher activity and $v_{\max } / K_{\mathrm{m}}$ value.

\section{Effects of supernatant sample volume}

To optimize sample volumes, increasing volumes of extracts from whole animal, rest of animal, visceral mass and gills were tested and the results are reported in Fig. 3. Assay conditions were as follows: $3 \mathrm{mM}$ substrate concentration, $\mathrm{pH} 7.5,25^{\circ} \mathrm{C}$. In each organ, AChE activity showed reaction rates directly proportional to the sample volume in the range 

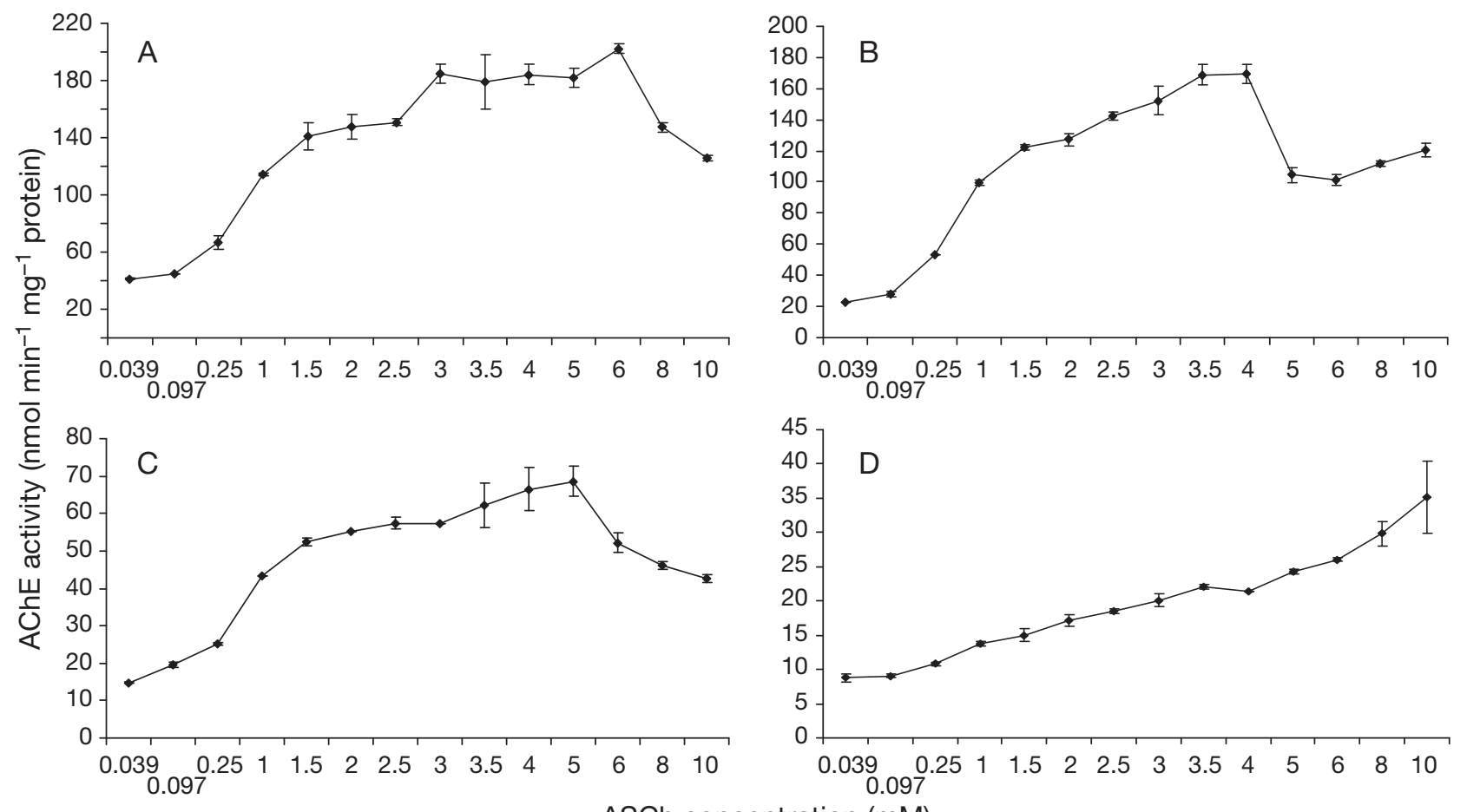

ASCh concentration (mM)

Fig. 2. Effects of substrate concentration on acetylcholinesterase (AChE) activity using acetylthiocholine (ASCh) as a substrate in tissues of the cockle Cerastoderma glaucum: (A) whole animal, (B) rest of animal (adductor and retractor muscles, mantle and foot), (C) visceral mass and (D) gills. Data are means \pm SD of triplicate determinations

tested. A volume of $40 \mu \mathrm{l}$ was therefore selected for all subsequent analyses.

\section{Field evaluation of $\mathrm{AChE}$ response in caged Cerastoderma glaucum}

To validate the use of AChE activity in biomonitoring the Tunisian coast, Cerastoderma glaucum individuals were transferred to the Téboulba fishing harbour for $30 \mathrm{~d}$ and AChE activity was evaluated in 2 tissue groups: the gills and the rest of the animal (adductor and retractor muscles, mantle and foot). Gills are considered an important route for uptake, bioconcentration and excretion of toxicants, and a prime target of contaminants because of the wide surface area in contact with the external medium and reduced distance between the internal and external medium. In caged cockles, gill AChE activity showed a time-dependent decrease and the Pearson coefficient was $-0.90(\mathrm{p}<0.01)$. Activity loss was approximately 15 and $68 \%$ after 15 and 30 d exposure, respectively (Fig. 4). In the rest of the animal, $\mathrm{AChE}$ activity decreased by approximately 30 and $24 \%$ after 15 and $30 \mathrm{~d}$, respectively, and the Pearson coefficient was $-0.55(p<0.05)$.
Table 1. Maximal velocity $\left(V_{\max }\right)$ and the Michaelis-Menten constant $\left(K_{\mathrm{m}}\right)$ of acetylcholinesterase in different tissue groups of Cerastoderma glaucum. $V_{\max } / K_{\mathrm{m}}$ is the catalytic efficiency. Results are expressed as the means \pm SD of triplicate determinations. Rest of animal: adductor and retractor muscles, mantle and foot

\begin{tabular}{|llcc|}
\hline Organ & $\begin{array}{c}V_{\max } \\
\left(\mathrm{nmol} \mathrm{min}^{-1}\right. \\
\left.\mathrm{mg}^{-1} \text { protein }\right)\end{array}$ & $\begin{array}{c}K_{\mathrm{m}} \\
(\mathrm{mM})\end{array}$ & $V_{\max } / K_{\mathrm{m}}$ \\
\hline Whole animal & $179.1 \pm 11.21$ & $0.34 \pm 0.14$ & 526.76 \\
Rest of animal & $141.6 \pm 10.92$ & $0.29 \pm 0.15$ & 488.27 \\
Visceral mass & $58.82 \pm 3.34$ & $0.21 \pm 0.09$ & 280.09 \\
Gills & $36.48 \pm 5.36$ & $2.06 \pm 0.87$ & 17.7 \\
\hline
\end{tabular}

\section{DISCUSSION}

Several studies have demonstrated the effectiveness of using measurement of ChE activity as a biomarker of exposure to neurotoxic compounds in bivalves, such as clams and mussels (Najimi et al. 1997, Dellali et al. 2001, Banni et al. 2005). Nevertheless, few data exist about the measurement of $\mathrm{ChE}$ activity in Cerastoderma glaucum (Machreki-Ajmi et al. 2008). There is also a general lack of knowledge of $\mathrm{ChE}$ activities in cockle species, regarding either 


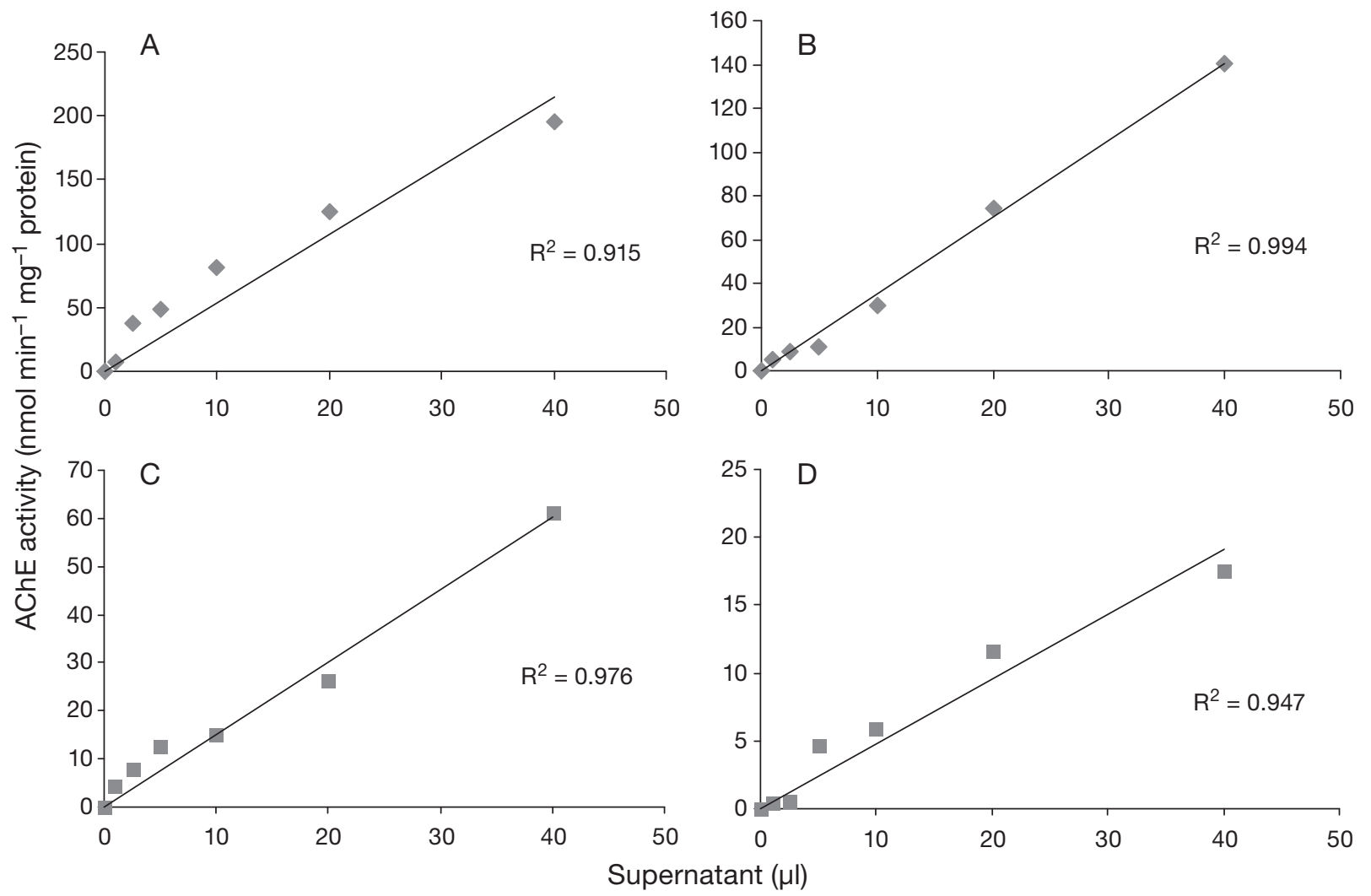

Fig. 3. Effects of variations in supernatant volume on acetylcholinesterase (AChE) activity using acetylthiocholine as substrate in (A) whole animal, (B) rest of animal (adductor and retractor muscles, mantle and foot), (C) visceral mass and (D) gills of the cockle Cerastoderma glaucum. Data are means \pm SD of duplicate determinations

their biochemical properties or their responses to pollutants in natural ecosystems. Nevertheless, such information is essential if these biomarkers are to be successfully used in biomonitoring programs for pollutant risk assessment. To our knowledge, this is the first time that ChE activities have been investigated

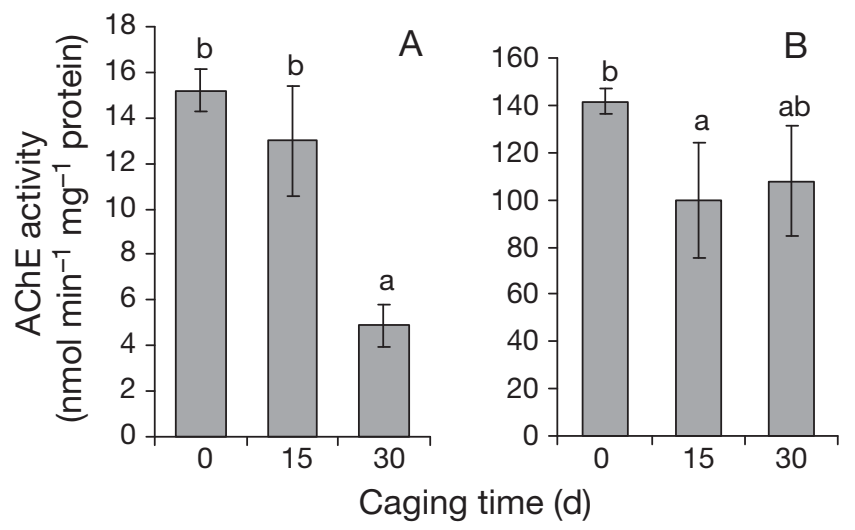

Fig. 4. Acetylcholinesterase (AChE) activity measured in (A) gills and (B) rest of animal (adductor and retractor muscles, mantle and foot) of the cockle Cerastoderma glaucum in cages in the Téboulba fishing harbour. Data are means \pm SD. Different lowercase letters indicate a significant difference between groups in tissues of the cockle C. glaucum. The basal levels of enzyme activities, substrate specificity and tissue distribution were characterized and the kinetic response under natural conditions was evaluated using a caging approach.

\section{Characterization of ChE activity in tissue groups}

The results of the preliminary screening of ChE activity in whole animal, rest of animal (adductor and retractor muscles, mantle and foot), visceral mass and gills of Cerastoderma glaucum (Fig. 1) show that the highest ChE activity was obtained using ASCh and PSCh, whereas the hydrolysis of BSCh was noticeably lower. These results agree with those obtained by Mora et al. (1999), who found PSCh and ASCh to be the most effective substrates for $\mathrm{ChE}$ in wholebody homogenates of the bivalve Corbicula fluminea. Similar results have also been reported for esterase activities by Bonacci et al. (2004), who found the following rank of substrate affinity in gill homogenates of Adamussium colbecki: $\mathrm{PSCh}>\mathrm{BSCh}=\mathrm{ASCh}$.

The results of the present study clearly confirm the presence of ChE activity in the main tissues of the 
cockle Cerastoderma glaucum and indicate that the enzyme activities using ASCh, PSCh and BSCh as substrates were tissue dependent. The results are in line with numerous studies on bivalves from different marine areas, although great variability of $\mathrm{ChE}$ basal levels in tissues, and variability in substrate specificity, have been recorded between species (Mora et al. 1999, Corsi et al. 2007). Several studies, showing a different ranking of substrate preference for esterase activities in bivalves such as Ostrea edulis (Valbonesi et al. 2003), clam Corbicula fluminea (Mora et al. 1999) and in other mollusc species (Bonacci et al. 2008), are in agreement with the well-accepted point of view that a high variability of esterase specificity to substrate often occurs both among different invertebrate species and within different tissues of the same organism (Gagnaire et al. 2008, Corsi et al. 2007, Valbonesi et al. 2003). In the present study, the $\mathrm{ChE}$ versus ASCh activity levels in the rest of the animal (adductor and retractor muscles, mantle and foot) are of the same order of magnitude as those found by Machreki-Ajmi et al. (2008) in rest of animal (foot, mantle, adductor muscles and siphons) of C. glaucum.

\section{Effects of substrate concentration and sample volume}

Regarding optimization of substrate concentrations, esterase activity with $\mathrm{AChE}$ in the whole animal, rest of animal and visceral mass showed a clear concentration-dependent pattern from 0.04 to $3 \mathrm{mM}$, and inhibition by excess substrate was observed at higher concentrations, depending on the selected tissue. A characteristic of the AChE enzyme is substrate inhibition (Massoulié \& Toutant 1988). For each selected tissue, the highest rates of hydrolysis were detected at the substrate concentration of $3 \mathrm{mM}$.

Differences were observed between $\mathrm{ChE}$ and ASCh activity in the gills, which displayed a more regular pattern of responses in the concentration range of 0.04 to $3.0 \mathrm{mM}$ than the other tissue groups, with the highest concentration eliciting the highest activities. Results similar to those of our study have previously been reported in molluscs (Bonacci et al. 2004, 2009).

Comparative analysis of the kinetic parameters $\left(v_{\max }, K_{\mathrm{m}}\right.$ and $\left.v_{\max } / K_{\mathrm{m}}\right)$ in tissues of Cerastoderma glaucum indicated that $\mathrm{ChE}$ versus ASCh activity was tissue-dependent and their level was following order: whole animal $>$ rest of animal $>$ visceral mass $>$ gills.

More detailed characterization of $\mathrm{ChE}$ activity using $\mathrm{ASCh}$ as a substrate in the tissue groups of
Cerastoderma glaucum was carried out by investigation of the effects of sample volume (Fig. 3). In each tissue, the reaction rate was linear and directly proportional to the sample volume in the range tested, in accordance with results reported by Bonacci et al. (2004) in the bivalve mollusc Adamussium colbecki.

\section{In situ study: AChE response in caged cockles}

Cerastoderma glaucum is considered a key species in the food web on the Tunisian coast, and is used to assess environmental health, particularly where mussels are rare. Furthermore, the tissue composition of bivalves reflects the variability of heavy metal levels in environmental matrices (Machreki-Ajmi \& Hamza-Chaffai 2006). In view of future national biomonitoring programmes, we illustrate the different sensitivity and kinetic response of AChE activity after caging exposure of C. glaucum at Téboulba fishing harbour. The use of caged bivalves is a useful strategy for monitoring marine pollution through the analysis of biomarker responses (Damiens et al. 2007). Transplanting bivalves from a reference site to a polluted area can reduce the influence of genetic and/or population differences, seasonal variability or adaptive phenomena, all of which can attenuate the capability to discriminate between different levels of environmental disturbance. The use of caged organisms provides a time-integrated assessment of environmental quality, and reveals the early biological effects induced by accumulated pollutants (Gorbi et al. 2008).

Cerastoderma glaucum caged at Téboulba fishing harbour for 4 wk experienced a critical alteration in gill AChE activity compared with the tissue activity of the rest of the animal (Fig. 4). In the gills, AChE activity decreased in a time-dependent pattern, losing approx. 15 and $68 \%$ activity after 2 and 4 wk of transplantation, respectively, whereas in muscle tissue (rest of animal) the loss of AChE was approximately $24 \%$ at the end of the 4 wk caging period. Consequently, different profile responses of $\mathrm{AChE}$ activity were noted and the gill seems to be more sensitive to the effect of harbour pollutants than the muscle. Similar results were obtained by Roméo et al. (2003), who noted a significant reduction in the AChE activity of mussels transplanted at harbour entrance in Cannes, France, attributed to the heavy metal concentration in mussel tissues. Téboulba harbour is a large fishing harbour built in 1970 and located in the center of the Tunisian littoral area. It is an economically important facility due to a variety of 
fishing activities and contributed $30 \%$ of the national fish captures in the last 5 yr. Because over 450 ships of varying size are based in Téboulba harbour, it receives contaminants released from ship traffic and waste from the fishing industry. Thus, the harbour represents a key potential pollutant source for the central Tunisian littoral (Jebali et al. 2007), and thus the higher concentrations of heavy metals, oils and fuels in the harbour environment may be responsible for the kinetic reduction of C. glaucum AChE activity.

\section{CONCLUSIONS}

We have demonstrated the presence of ChE activity in tissue groups of the cockle Cerastoderma glaucum (whole animal, rest of animal [adductor and retractor muscles, mantle and foot], visceral mass and gills). The present study emphasizes the importance of standardizing the optimal conditions for measuring $\mathrm{AChE}$ activity in different tissues. Moreover, results showed that $\mathrm{AChE}$ activity diminished in a time-dependent pattern in a caging exposure of $C$. glaucum, highlighting the potential of such ecotoxicological tools for the assessment of the marine quality of the Tunisian and Mediterranean ecosystems. Further ecotoxicological characterization studies focused on the kinetic uptake of chemical pollutants (PAHs and heavy metals) and AChE activity response of $C$. glaucum during increasing periods of caging/depuration will be carried out in the future.

Acknowledgements. This work was supported by a fund from the Ministry of Scientific Research and Technology, Sousse University, Tunisia (Research Unit of Biochemistry and Environmental Toxicology, UR 04AGR05), and the Institution of Research and Agricultural Higher Education (Tunisia). We wish to acknowledge the suggestions and comments of the anonymous reviewers, which helped to improve the quality of the manuscript.

\section{LITERATURE CITED}

Banni M, Jebali J, Daubeze M, Clerandau C, Guerbej H, Narbonne JF, Boussetta H (2005) Monitoring pollution in Tunisian coasts: application of a classification scale based on biochemical markers. Biomarkers 10:105-116

Bocquené G, Galgani F (1991) L'acétylcholinestèrase chez les organismes marins, outil de surveillance des effets des pesticides organophosphorés et carbamates. Oceanis 17:439-448

> Bocquené G, Roig A, Fournier D (1997) Cholinesterases from the common oyster (Crassostrea gigas): evidence for the presence of a soluble acetylcholinesterase insensitive to organophosphate and carbamate inhibitors. FEBS Lett 407:261-266
Bonacci S, Browne MA, Dissanayake A, Hagger JA, Corsi I, Focardi S, Galloway TS (2004) Esterase activities in the bivalve mollusc Adamussium colbecki as a biomarker for pollution monitoring in the Antarctic marine environment. Mar Pollut Bull 49:445-455

Bonacci S, Corsi I, Focardi S (2008) Cholinesterase activities in the scallop Pecten jacobaeus: characterization and effects of exposure to aquatic contaminants. Sci Total Environ 392:99-109

> Bonacci S, Corsi I, Focardi S (2009) Cholinesterases in the Antarctic scallop Adamussium colbecki: characterization and sensitivity to pollutants. Ecotoxicol Environ Saf 72: 1481-1488

> Bradford MM (1976) A rapid and sensitive method for the quantification of microgram quantities of protein utilizing the principal of protein-dye binding. Anal Biochem 72:248-254

Corsi I, Pastore AM, Lodde A, Palmerini E, Castagnolo L, Focardi S (2007) Potential role of cholinesterases in the invasive capacity of the freshwater bivalve, Anodonta woodiana (Bivalvia: Unionacea): a comparative study with the indigenous species of the genus, Anodonta sp. Comp Biochem Physiol C 145:413-419

Damiens G, Gnassia-Barelli M, Loquès F, Roméo M, Salbert $\mathrm{V}$ (2007) Integrated biomarker response index as a useful tool for environmental assessment evaluated using transplanted mussels. Chemosphere 66:574-583

Dellali M, Gnassia Barelli M, Romeo M, Aissa P (2001) The use of acetylcholinesterase activity in Ruditapes decussatus and Mytilus galloprovincialis in the biomonitoring of Bizerta lagoon. Comp Biochem Physiol 130:227-235

Ellman GL, Courtneyk D, Andres V, Featherstone RM (1961) A new and rapid colorimetric determination of acetylcholinesterase activity. Biochem Pharmacol 7:88-95

> Gagnaire B, Geffard O, Xuereb B, Margoum C, Garric J (2008) Cholinesterase activities as potential biomarkers: characterization in two freshwater snails, Potamopyrgus antipodarum (Mollusca, Hydrobiidae, Smith 1889) and Valvata piscinalis (Mollusca, Valvatidae, Müller 1774). Chemosphere 71:553-560

Galloway TS, Millward N, Browne MA, Depledge $\mathrm{MH}$ (2002) Rapid assessment of organophosphorous/carbamate exposure in the bivalve mollusc Mytilus edulis using combined esterase activities as biomarkers. Aquat Toxicol 61:169-180

> Gorbi S, Virno Lamberti C, Notti A, Benedetti M, Fattorini D, Moltedo G, Regoli F (2008) An ecotoxicological protocol with caged mussels, Mytilus galloprovincialis, for monitoring the impact of an offshore platform in the Adriatic sea. Mar Environ Res 65:34-49

> Jebali J, Banni M, De Almeida EA, Boussetta H (2007) Oxidative DNA damage levels and catalase activity in the clam Ruditapes decussatus as pollution biomarkers of Tunisian marine environment. Environ Monit Assess 124:195-200

López-Barea J (1995) Biomarkers in ecotoxicology: an overview. In: Degen GH, Seiler JP, Bentley P (eds) Toxicology in transition, Archives of Toxicology, Supplement 17. EUROTOX Proceedings. Springer-Verlag, Berlin, p 57-79

Machreki-Ajmi M, Hamza-Chaffai A (2006) Accumulation of cadmium and lead in Cerastoderma glaucum originating from the Gulf of Gabès, Tunisia. Bull Environ Contam Toxicol 76:529-537

Machreki-Ajmi M, Ketata I, Ladhar-Chaabouni R, HamzaChaffai A (2008) The effect of in situ cadmium contami- 
nation on some biomarkers in Cerastoderma glaucum. Ecotoxicology 17:1-11

Massoulié J, Toutant JP (1988) Vertebrate cholinesterases: structures and types of interaction. Handb Exp Pharmacol 86:167-224

Massoulié J, Pezzementi L, Bon S, Krejci E, Vallette FM (1993) Molecular and cellular biology of cholinesterase. Prog Neurobiol 41:31-91

Massoulié J, Perrier N, Noureddine H, Liang D, Bon S (2008) Old and new questions about cholinesterases. Chem Biol Interact 175:30-44

Monserrat JM, Bianchini A (1998) Some kinetic and toxicological characteristics of thoracic ganglia cholinesterase of Chasmagnathus granulata (Decapoda, Grapsidae). Comp Biochem Physiol C 120:193-199

Mora P, Michel X, Narbonne JF (1999) Cholinesterase activity as a potential biomarker in two bivalves. Environ Toxicol Pharmacol 7:253-260

Najimi S, Bouhaimi A, Daubèze M, Zekhnini A, Pellerin J, Narbonne JF (1997) Use of acetylcholinesterase in Perna perna and Mytilus galloprovincialis as a biomarker of pollution in Agadir Marine Bay (South of Morocco). Bull Environ Contam Toxicol 58:901-908

Oikari A (2006) Caging techniques for field exposures of fish to chemical contaminants. Aquat Toxicol 78:370-381

Roméo M, Hoarau P, Garello G, Gnassia-Barelli M, Girard JP (2003) Mussel transplantation and biomarkers as useful tools for assessing water quality in the NW Mediter-

Editorial responsibility: Peter Beninger,

Nantes, France ranean. Environ Pollut 122:369-378

Sturm A, Da Silva de Assis HC, Hansen PD (1999) Cholinesterases of marine teleost fish: enzymological characterization and potential use in the monitoring of neurotoxic contamination. Mar Environ Res 47:389-398

Valbonesi P, Sartor G, Fabbri E (2003) Characterization of cholinesterase activity in three bivalves inhabiting the North Adriatic Sea and their possible use as sentinel organisms for biosurveillance programmes. Sci Total Environ 312:79-88

Vioque-Fernández A, Alves de Almeida E, Ballesteros J, García-Barrera T, Gómez-Ariza JL, López-Barea J (2007) Dõnana National Park survey using crayfish (Procambarus clarkii) as bioindicator: esterase inhibition and pollutant levels. Toxicol Lett 168:260-268

Vioque-Fernández A, Alves de Almeida E, López-Barea J (2009a) Assessment of Doñana National Park contamination in Procambarus clarkii: integration of conventional biomarkers and proteomic approaches. Sci Total Environ 407:1784-1797

Vioque-Fernández A, Alves de Almeida E, López-Barea J (2009b) Biochemical and proteomic effects in Procambarus clarkii after chlorpyrifos or carbaryl exposure under sublethal conditions. Biomarkers 14:299-310

Xuereb B, Noury P, Felten V, Garric J, Geffard O (2007) Cholinesterase activity in Gammarus pulex (Crustacea Amphipoda): characterization and effects of chlorpyrifos. Toxicology 236:178-189

Submitted: April 4, 2010; Accepted: June 27, 2011

Proofs received from author(s): October 4, 2011 